\title{
CLIFF-NESTING COMMON MERGANSER AT URANIUM CITY
}

by Frank A. Heidelbaver, 2317 East 17th St., Sioux Falls, S.D.

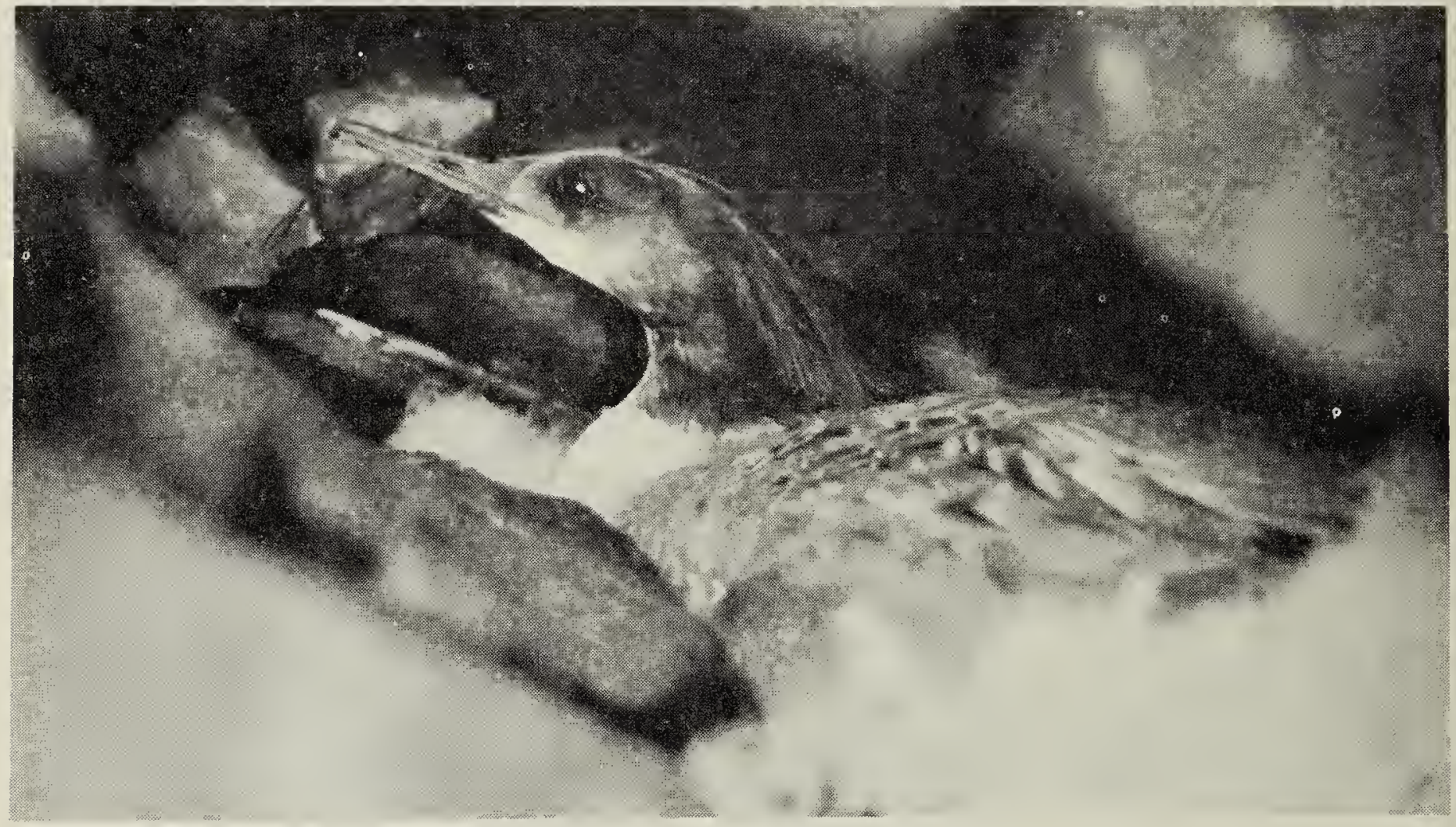

Cliff-nesting Common Merganser at Donaldson Lake,

Uranium City, Saskatchewan, June 12, 1966

In 1966 and again in 1967, I found a Common Merganser nesting on a cliff on the edge of Donaldson Lake, eight miles northeast of Uranium City. R. W. Nero (1963. Birds of the Lake Athabasca region, Saskatchewan. S.N.H.S. Spec. Pub. No. 5) reported finding mergansers which were apparently nesting on a cliff at Carswell Lake to the south of Lake Athabasca, but he was unable to find

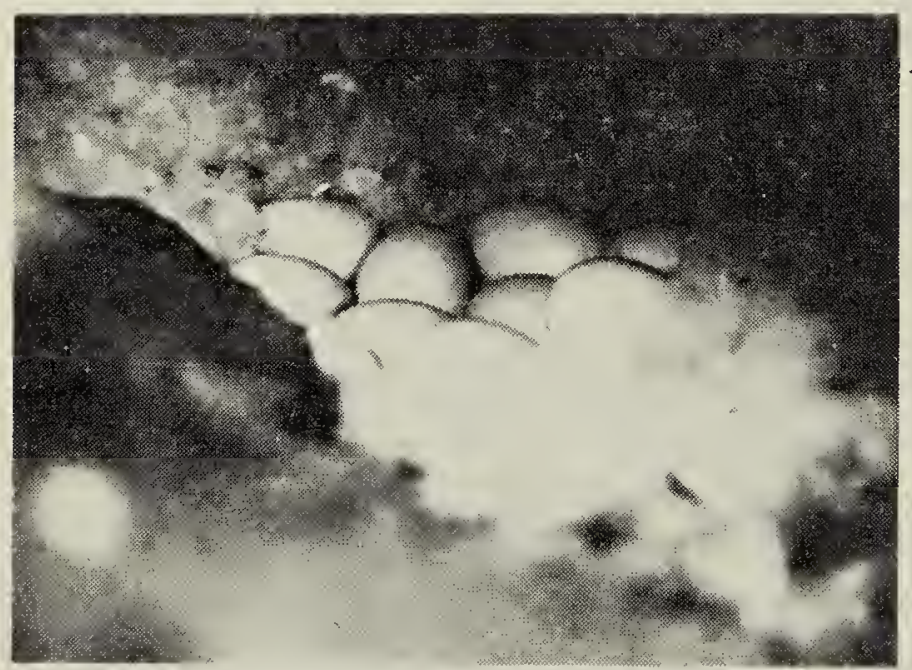

Eggs of Common Merganser, Donaldson Lake, June 17, 1966 a nest. Thus, this is apparently the first definite observation of cliffnesting mergansers for Saskatchewan.

Donaldson Lake is accessible by car or truck via a fair mining road to some claims in the area. Many Uranium City residents fish the lake which abounds with lake trout 12 to 14 inches long. The cliff is on the southwest end of the lake where the access road meets the lake. On June 17, 1966, I scaled the cliff, which was about 110 feet high, to check a nest near the top that appeared to be a defunct raven nest. While I was resting in the deep shade of a boulder about half-way down the cliff, I saw a merganser coming in off the lake flying almost right at me. To my surprise she entered a hole about 10 feet from my position. Checking, I found her on a nesit near the opening, but she immediately retreated into a deep recess back in the cliff; from this point of security she hissed vigorously. 
